\title{
THE PRODUCTION OF NEURAMINIDASE BY FOOD- POISONING STRAINS OF CLOSTRIDIUM WELCHII (C. PERFRINGENS)
}

\author{
A. G. Fraser and J. G. Collee \\ Department of Bacteriology, Medical School, University of Edinburgh, Teviot Place, \\ Edinburgh EH8 $9 A G$
}

THERE is confusion in the literature regarding the production of neuraminidase (EC 3.2.1.18) by food-poisoning strains of Clostridium welchii (C.perfringens) type $\mathrm{A}$; this partly reflects the changing definition of these food-poisoning strains. Many episodes of food poisoning caused by $C$. welchii result from ingestion of strains that produce very heat-resistant spores, i.e., spores that survive boiling in faecal suspension for $1 \mathrm{~h}$ or more (Hobbs et al., 1953). These strains, which are also non-haemolytic, have been considered as " typical food-poisoning" strains. Although such strains are most likely to survive cooking procedures, it is now well recognised that food poisoning can also be caused by strains that produce relatively heat-sensitive spores, and these strains may be haemolytic or non-haemolytic (Hauschild and Thatcher, 1967; Sutton and Hobbs, 1968; Hobbs, 1969). Food-poisoning strains of $C$. welchii are serotyped with two sets of antisera, one for the typical heat-resistant strains-Hobbs' types 1-24-and the other for the so-called heat-sensitive strains-types i-xviii (Hobbs et al., 1973).

Collee was unable to show neuraminidase production in cultures of four British typical food-poisoning strains but, because culture supernates of two strains produced a myxovirusreceptor-inactivating effect on red cells (Collee, 1965a), he concluded that " more extensive investigation is required before it can be claimed that neuraminidase is never produced by typical food-poisoning strains" (Collee, 1965b).

Moss, Schekter and Cherry (1967), working in the United States, surveyed many strains of $C$. welchii for neuraminidase activity. These workers confirmed that the reference British heat-resistant food-poisoning strains examined by them did not produce neuraminidase, but they showed that one of five American food-poisoning strains of $C$. welchii that could not otherwise be differentiated from these strains was neuraminidase positive. American foodpoisoning strains generally include many that are haemolytic or heat-sensitive or both; the majority of American food-poisoning strains examined by Moss et al. (1967) did produce neuraminidase.

In the present study, the more sensitive neuraminidase-assay procedure described by Fraser and Smith (1975) was used for a further investigation of neuraminidase production in a range of heat-resistant and heat-sensitive British food-poisoning strains of $C$. welchii.

Received 2 Aug. 1974; accepted 25 Sept. 1974.

J. MED. MICROBIOL.-VOL. 8 (1975) 


\section{MATERIALS AND METHODS}

Strains of $C$. welchii. Four classical haemolytic strains of $C$. welchii type A were used. Strain L2Ab was described in the previous paper (Fraser and Smith, 1975); strain L3A was also obtained from Professor C. L. Oakley, School of Medicine, University of Leeds. Strains $\mathrm{C} 1$ and 032 were laboratory strains originally isolated from wound infections in Edinburgh.

Typical non-haemolytic, heat-resistant, food-poisoning strains of $C$. welchii type A of Hobbs' types 1-4 (Nos. 8359, 8238, 8239 and 8247 respectively) were obtained from the National Collection of Type Cultures, Colindale, London; strains of Hobbs' types 5-24 were kindly provided by Dr Betty Hobbs, Central Public Health Laboratory, Colindale. Strains 029 and 153 were typical food-poisoning strains isolated from separate food-poisoning outbreaks in Edinburgh (Collee, 1965b); they were submitted to Dr Hobbs, who reported that they were both type-13 strains. Strains 611 and 4621 were provided by Dr Hobbs: these were non-haemolytic type-13 strains but were not responsible for actual food-poisoning outbreaks; strain 611 was isolated post mortem from a patient with colitis and strain 4621 from a patient who died during a food-poisoning outbreak attributed to a different strain of $C$. welchii. Reference food-poisoning strains of $C$. welchii type A that do not produce heatresistant spores (types $\mathrm{i}$-iii, v-xviii) were provided by Dr Hobbs, and are referred to as heatsensitive strains.

Media and method of anaerobic culture. Cooked-meat broth and Proteose Peptone-water medium (PPW5) were described in the previous paper (Fraser and Smith, 1975). ToddHewitt Broth and Nutrient Broth (No. 2) were manufactured by Oxoid Ltd. Horse-blood agar contained Columbia Agar Base with $10 \%$ (v/v) defibrinated horse blood (Oxoid). Anaerobic culture methods were as previously described (Fraser and Smith, 1975) with a gas mixture of $10 \%(\mathrm{v} / \mathrm{v}) \mathrm{CO}_{2}$ and $90 \% \mathrm{H}_{2}$ used as a routine.

Observation of haemolytic effect. Strains were grown anaerobically on horse-blood agar for $18 \mathrm{~h}$ at $37^{\circ} \mathrm{C}$ with $10 \% \mathrm{CO}_{2}$. Strains graded as haemolytic produced clear haemolysis, with or without a surrounding zone of incomplete haemolysis. Non-haemolytic strains produced no effect or only a small zone of faint, incomplete haemolysis.

Serial culture of strains for tests of neuraminidase production. In general, a $0 \cdot 1-\mathrm{ml}$ inoculum of an overnight anaerobic cooked-meat broth culture was added to $10 \mathrm{ml}$ of pre-steamed culture medium in a tube and incubated anaerobically for $48 \mathrm{~h}$. Serial 48-h cultures were made in this manner with a $0.1-\mathrm{ml}$ inoculum for each passage. A $5-\mathrm{ml}$ sample of centrifuged supernate $\left(800 \mathrm{~g}\right.$ for $1 \mathrm{~h}$ at $\left.4^{\circ} \mathrm{C}\right)$ from each passage was stored at $-20^{\circ} \mathrm{C}$. Cultures were incubated at $37^{\circ} \mathrm{C}$ unless otherwise indicated.

Disruption of washed cells. Five serial cultures were made in PPW5 broth, incubated on each occasion for $48 \mathrm{~h}$ at $39^{\circ} \mathrm{C}$. Cultures 1,2 and 3 were made by transferring $0.1 \mathrm{ml}$ of culture into $10 \mathrm{ml}$ of medium as for the serial cultures described above. For the fourth culture, a $1 \cdot 0-\mathrm{ml}$ inoculum was added to $100 \mathrm{ml}$ medium and, for the fifth, $10 \mathrm{ml}$ was added to $500 \mathrm{ml}$. Samples $(5 \mathrm{ml})$ of centrifuged supernates $\left(800 \mathrm{~g}\right.$ for $1 \mathrm{~h}$ at $\left.4^{\circ} \mathrm{C}\right)$ from the first four cultures were stored at $-20^{\circ} \mathrm{C}$. After centrifugation $\left(2000 \mathrm{~g}\right.$ for $1 \mathrm{~h}$ at $4^{\circ} \mathrm{C}$ ) the supernate of the fifth serial culture was stored at $-20^{\circ} \mathrm{C}$ and the packed cells were resuspended in $20 \mathrm{ml}$ of sterile normal saline. The cells were washed three times in saline $\left(2000 \mathrm{~g}\right.$ for $1 \mathrm{~h}$ at $\left.4^{\circ} \mathrm{C}\right)$ and the washed cells were resuspended in $20 \mathrm{ml}$ of saline. The resuspended washed cells and samples of the supernate from each washing were held at $-20^{\circ} \mathrm{C}$.

The washed cell suspension was later thawed and four 3-ml samples of each organism were subjected to ultrasonic disruption (MSE-Mullard Ultrasonic Disintegrator) for $1 \mathrm{~h}$ with the samples held at $0^{\circ}-1^{\circ} \mathrm{C}$ in an ice bath. This produced a great decrease in turbidity in the samples, and phase-contrast microscopy confirmed a reduction in the number of intact cells to less than $1 \%$ of the original. The treated samples were pooled and the centrifuged supernate $\left(20,000 \mathrm{~g}\right.$ for $1 \mathrm{~h}$ at $\left.4^{\circ} \mathrm{C}\right)$ was held at $-20^{\circ} \mathrm{C}$.

Concentration and dialysis of culture supernates. Samples of culture supernate $(100 \mathrm{ml})$ were concentrated in $2.5-\mathrm{cm}$ Visking cellophane tubing exposed to polyethylene glycol (mol. wt. 6000) for $20 \mathrm{~h}$ at $4^{\circ} \mathrm{C}$, and thereafter dialysed against large quantities of distilled water for $72 \mathrm{~h}$ at $4^{\circ} \mathrm{C}$. 
Assay for neuraminidase activity. The reagents and procedures are described in the previous paper (Fraser and Smith, 1975). The assay was standardised with reaction mixtures prepared as follows: test substance, $0.1 \mathrm{ml}$; sodium acetate buffer, $p \mathrm{H} 5.1,0.15 \mathrm{ml}$; and substrate FVII diluted in the acetate buffer, $0.25 \mathrm{ml}$. The original batch of substrate, FVII(5), was used at a final concentration of $3.07 \mathrm{mg}$ per $\mathrm{ml}$ in the $0.5-\mathrm{ml}$ test volume and the second batch, FVII(6), at $4.0 \mathrm{mg}$ per $\mathrm{ml}$. Separate enzyme and substrate controls were assayed and used to correct the test results. Test and control mixtures were incubated at $37^{\circ} \mathrm{C}$ in a water bath for the appropriate length of time before the assay for free $\mathrm{N}$-acetyl neuraminic acid (NANA). Duplicate mixtures were usually assayed, and the amount of NANA released is indicated in terms of the corrected average extinction values at $549 \mathrm{~nm}\left(E_{549}\right)$. In progress experiments, the timing was such that all tests, including time-zero $\left(T_{0}\right)$ control tests, were assayed for NANA in one batch; $T_{0}$ test values were used for correction of test readings (Fraser and Smith, 1975).

Tests for the effects of culture materials on the NANA assay. These have been described in the previous paper, in which control assays and calculations are detailed (Fraser and Smith, 1975). Mixtures were prepared as for the standard neuraminidase assay but with $10 \mu \mathrm{g}$ of pure NANA in $0.25 \mathrm{ml}$ of distilled water in place of the substrate.

\section{RESULTS}

Production of neuraminidase by classical strains of $C$. welchii grown in various broth media

Four classical (haemolytic, heat-sensitive) strains of $C$. welchii type A were cultured for $48 \mathrm{~h}$ in a range of broth media, and a second serial culture was made from each in the same medium. The results of neuraminidase assays on the supernates of the second serial cultures (table I) indicate that neuraminidase production is poor in nutrient broth and generally good in PPW5 broth and Todd-Hewitt medium. These results reflect our experience with many strains of $C$. welchii; PPW5 broth and Todd-Hewitt medium give generally good yields of neuraminidase, but yields may vary markedly even in successive cultures of the same strain grown under apparently identical conditions in

\section{TABLE I}

Production of neuraminidase by four classical strains of Clostridium welchii type A grown in four broth media

\begin{tabular}{l|llll}
\hline \multirow{2}{*}{$\begin{array}{c}\text { Strain } \\
\text { number }\end{array}$} & \multicolumn{4}{|c}{$\begin{array}{l}\text { Result of neuraminidase assay on supernate from } \\
\text { second serial culture in stated medium }\left(E_{549}\right)^{*}\end{array}$} \\
\cline { 2 - 5 } & NB & CMB & THB & PPW5 \\
& & & & \\
\hline & & & & \\
L2Ab & 0.315 & 0.732 & 1.320 & 0.640 \\
L3A & 0.056 & 0.190 & 0.656 & 1.052 \\
C1 & 0.280 & 0.441 & 0.692 & 0.920 \\
032 & 0.346 & 0.649 & 1.900 & 0.492 \\
\hline
\end{tabular}

* The spectrophotometric value $\left(E_{549}\right)$ is an average result obtained from duplicate 15 -min. assay readings corrected by subtraction of the values for the substrate control and the corresponding enzyme control.

$\mathrm{NB}=$ nutrient broth; $\mathrm{CMB}=$ cooked-meat broth; $\mathrm{THB}=$ Todd-Hewitt broth; PPW5 $=5 \%$ Proteose Peptone water. 
TABLE II

Production of neuraminidase by heat-resistant and heat-sensitive reference food-poisoning strains of $C$. welchii type $A^{*}$

\begin{tabular}{l|ccc}
\hline Reference strains & $\begin{array}{c}\text { Haemolytic effect } \\
\text { on blood agart }\end{array}$ & $\begin{array}{c}\text { Serotype numbers of } \\
\text { neuraminidase- } \\
\text { positive strains } \ddagger\end{array}$ & $\begin{array}{c}\text { Serotype numbers of } \\
\text { neuraminidase- } \\
\text { negative strains }\end{array}$ \\
\hline $\begin{array}{c}\text { Hobbs' types 1-24 } \\
\text { (heat-resistant) }\end{array}$ & $\mathrm{NH}$ & $13,18,21,24$ & $\begin{array}{c}1,2,3,4,5,6,7,8,9,10, \\
11,12,14,15,16,17, \\
19,20,22,23\end{array}$ \\
$\begin{array}{c}\text { Hobbs' types i-xviii } \\
\text { (heat-sensitive) }\end{array}$ & $\mathrm{NH}$ & $\mathrm{i}, \mathrm{ix}$ & xiii, xiv, xv \\
viii
\end{tabular}

* Tests performed on supernates of second serial 48-h cultures in PPW5 broth.

+ See Materials and Methods; $\mathrm{H}=$ haemolytic; $\mathrm{NH}=$ non-haemolytic.

I Tests incubated with substrate FVII at $37^{\circ} \mathrm{C}$. Supernates of most cultures gave clearly positive results in assays incubated for $15 \mathrm{~min}$.; assays of supernates of strains belonging to serotypes 24 and $\mathrm{i}$ were incubated for $4 \mathrm{~h}$ to produce clearly significant assay values.

$\S$ Tests incubated with substrate FVII at $37^{\circ} \mathrm{C}$ for $24 \mathrm{~h}$ gave negative results.

samples of medium prepared in a single batch (see fig. 1 below). On occasion, cultures in PPW5 broth were unduly mucoid; this occurred rather more frequently in Todd-Hewitt medium but was not correlated with variations in neuraminidase production. The amount of neuraminidase present in the supernate of cultures in PPW5 broth reaches a maximum within $24 \mathrm{~h}$ and there is no significant increase or decrease in activity between 24 and $72 \mathrm{~h}$. In later studies we found that the production of neuraminidase by strain $\mathrm{L} 2 \mathrm{Ab}$ in 48-h cultures in PPW5 broth was markedly influenced by the temperature of incubation of the culture within the range $35-42^{\circ} \mathrm{C}$; the maximum

\section{TABLE III}

Production of neuraminidase by strain $L 2 A b$ and by five strains of $C$. welchii of Hobbs' type 13

\begin{tabular}{c|c}
\hline $\begin{array}{c}\text { Strain } \\
\text { number }\end{array}$ & $\begin{array}{c}\text { Result of neuraminidase assay } \\
\text { on supernate from second serial } \\
\text { culture in PPW5 broth }\left(E_{549}\right)^{*}\end{array}$ \\
\hline L2Ab & 0.579 \\
NCTC10240† & 0.149 \\
029 & 0.163 \\
153 & 0.172 \\
611 & 0.531 \\
4621 & $0.000 \ddagger$ \\
\hline
\end{tabular}

- See footnote to table I.

+ Hobbs' type-13 reference strain.

\pm The negative result for the culture supernate of strain 4621 was confirmed when the period of incubation of the test was extended to $24 \mathrm{~h}$. 
TABLE IV

Neuraminidase activity in various culture products of strain L2Ab grown in PPW5 broth

\begin{tabular}{l|c}
\hline \multicolumn{1}{c|}{ Product of serial culture* } & $\begin{array}{c}\text { Result of neuraminidase } \\
\text { assay }\left(E_{549} \dagger\right.\end{array}$ \\
\hline Supernate 1 & $5 \cdot 480$ \\
Supernate 2 & 2.120 \\
Supernate 3 & $3 \cdot 404$ \\
Supernate 4 & $3 \cdot 672$ \\
Supernate 5 & 3.088 \\
Supernate 5 concentrateł & 13.640 \\
1st washing from bacillary deposit 5 & 0.433 \\
2nd washing & 0.032 \\
3rd washing & 0.021 \\
Extract of sonicated washed deposit 5 & $1 \cdot 428$ \\
\hline
\end{tabular}

* See Materials and Methods.

$\dagger$ See footnote to table I. (Samples diluted appropriately before assay).

\$Concentrated to $22.1 \%$ of the original volume.

yield obtained at $39-40^{\circ} \mathrm{C}$ may be up to twice that obtained at $35^{\circ} \mathrm{C}$. Minor differences in the temperature of incubation may contribute to the variation in amount of neuraminidase produced in serial cultures.

\section{Production of neuraminidase by food-poisoning strains of $C$. welchii}

We chose to test the supernate of the second serial 48-h culture in PPW5 broth at $37^{\circ} \mathrm{C}$ as a routine procedure in the present studies. The results of neuraminidase assays on 41 reference food-poisoning strains of $C$. welchii are presented in table II. The culture supernates were first tested in a screening assay incubated with FVII substrate for $1 \mathrm{~h}$; thereafter, positive supernates were assayed at appropriate dilutions by a standard 15-min. assay procedure. Two supernates gave very low readings in the 1-h screening assay; these were assayed in tests incubated for $4 \mathrm{~h}$ to produce clearly significant readings. Supernates that were negative in the 1-h screening assay were then tested with 24-h incubation; all remained negative. Most of the typical non-haemolytic, heat-resistant $C$. welchii strains were neuraminidase negative, but there was good production of neuraminidase by the strains of Hobbs' types 13, 18 and 21 and the strain of Hobbs' type 24 produced a small amount of activity. Thirteen of the 17 heat-sensitive food-poisoning strains produced neuraminidase, but the remaining four strains were completely negative. It appears that in general non-haemolytic strains do not produce neuraminidase whereas haemolytic strains do, though there are clear exceptions to this general correlation.

A further four type-13 strains were tested for neuraminidase production in this way. Strains 029 and 153 were isolated from food-poisoning outbreaks in Edinburgh and strains 611 and 4621 were supplied by Dr Hobbs. The results presented in table III show production of a moderate amount of neuraminidase by strain 611 and rather small amounts by the reference strain 10240 


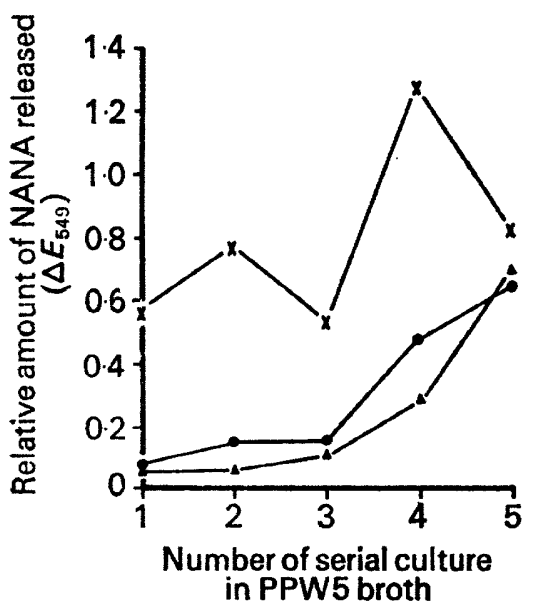

FIG. 1

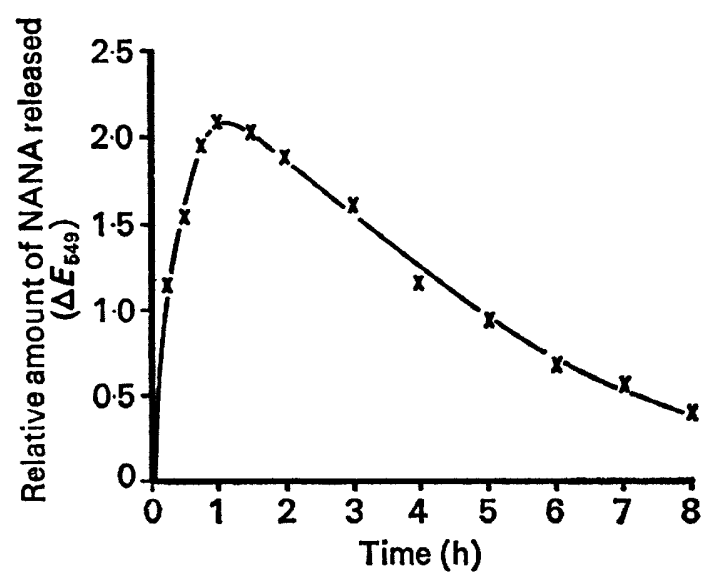

FIG. 2

FIG. 1.-Corrected test results of 15-min. neuraminidase assays of supernates of serial cultures of C. welchii strains in PPW5 broth: $\times-x$, strain $\mathrm{L} 2 \mathrm{Ab} ; \triangle-\Lambda$, strain 153 ; strain 029 . Strain L2Ab supernates were assayed at a dilution of 1 in 4 in acetate buffer, $p H 5 \cdot 1$, and the values corrected accordingly; supernates of strains 153 and 029 were assayed undiluted.

Fig. 2.-Release and destruction of NANA during neuraminidase assays on undiluted L2Ab cell extract for up to $8 \mathrm{~h}$. The relative amount of free NANA is plotted as the spectrophotometric reading $\left(E_{549}\right)$ of single-tube assays corrected by subtraction of the value for the time-zero test. The assay product for each test was diluted 1 in 5 in reagent 4 (acid butanol) before reading and the results were corrected accordingly.

and by strains 029 and 153; nevertheless, activity was clearly demonstrable after incubation of tests for $15 \mathrm{~min}$. By contrast, there was no activity in the supernate of strain 4621 even when the tests were incubated for $24 \mathrm{~h}$. When a sample of this supernate was incubated with NANA for $24 \mathrm{~h}$ under conditions equivalent to those of the neuraminidase assay there was no significant reduction in the assay value for NANA. Thus the negative result in the 24-h neuraminidase assay with the supernate of strain 4621 was not due to destruction of NANA by $\mathrm{N}$-acyl neuraminic acid-aldolase (NAN-aldolase : $\mathrm{N}$-acyl neuraminate lyase, EC 4.1.3.3).

\section{Variability of neuraminidase production during serial culture}

Five serial cultures of the classical strain L2Ab and the weakly neuraminidase-positive food-poisoning strains 029 and 153 were made in 10-ml volumes of PPW5 broth. The results of the standard 15-min. assay for neuraminidase activity in the supernates of these cultures are presented in fig. 1. Strain L2Ab produced moderate but variable yields of neuraminidase in all supernates. Initially, the two Edinburgh food-poisoning strains produced small amounts of neuraminidase but this increased in serial cultures until by the fifth culture the activity was comparable with that produced by strain $\mathrm{L} 2 \mathrm{Ab}$. The presence of neuraminidase activity in the supernates of the 
first cultures in this series was confirmed by demonstrating that more NANA was released when the period of incubation was extended. In tests in which samples of supernate were incubated with a standard amount of NANA for 15 min., there was no significant breakdown of NANA. The values plotted in fig. 1 therefore give a valid indication of the relative amounts of neuraminidase produced by the three strains in this experiment. These results might suggest that sequential culture in PPW5 broth of strains 029 and 153 produces a gradually increased yield of neuraminidase. However, further experiments with organisms derived from freeze-dried stocks and grown under apparently identical conditions did not show this pattern; the initial cultures often produced high amounts of the enzyme and variations in yield could not be attributed to any particular variable in experimental conditions.

\section{Assays for cell-associated neuraminidase}

Five serial cultures of the neuraminidase-positive classical strain L2Ab and the neuraminidase-negative food-poisoning strain Hobbs' 2 were made successively at $39^{\circ} \mathrm{C}$ in 10-, 10-, 10-, 100- and 500-ml volumes of PPW5 broth. Samples $(100 \mathrm{ml})$ of culture supernates from the fifth serial cultures were concentrated approximately five-fold; the L2Ab culture was concentrated to $22.1 \%$ of its original volume, and the Hobbs' type- 2 culture to $17.8 \%$, after dialysis (see Materials and Methods). The washed cells from the $500 \mathrm{ml}$ of the fifth serial cultures were resuspended in $20 \mathrm{ml}$ saline and disrupted ultrasonically; the resultant suspension was then centrifuged free of cell debris and is referred to as cell extract. Table IV presents the results of neuraminidase assays on the culture products of strain L2Ab from this experiment. The 15min. neuraminidase assays show very high yields in the supernates, of all

\section{TABLE V}

Effect of incubating $N$-acetyl neuraminic acid (NANA) with culture supernates of strain L2Ab and the Hobbs' type-2 strain for up to $24 h$

\begin{tabular}{|c|c|c|c|c|c|c|}
\hline \multirow{2}{*}{ Reaction mixture* } & \multicolumn{6}{|c|}{$\begin{array}{l}\text { Result of assay for NANA }\left(E_{549}\right) \dagger \text { after incubation of } \\
\text { mixture for stated time (h) }\end{array}$} \\
\hline & $\mathbf{0}$ & $\frac{1}{2}$ & 2 & 3 & 22 & 24 \\
\hline \multirow{4}{*}{$\begin{array}{l}\text { NANA alone } \\
\text { NANA + supernate of 5th serial } \\
\text { culture of strain L2Ab } \\
\text { NANA+ supernate of 5th serial } \\
\text { culture of Hobbs' type-2 strain } \\
\text { NANA+ concentrated supernate of } \\
\text { 5th serial culture of Hobbs' type-2 } \\
\text { strain }\end{array}$} & 0.514 & 0.514 & 0.506 & 0.530 & 0.531 & 0.537 \\
\hline & 0.516 & 0.502 & 0.474 & 0.474 & $0 \cdot 299$ & $\ldots$ \\
\hline & 0.503 & 0.500 & 0.494 & 0.511 & 0.511 & 0.500 \\
\hline & 0.548 & 0.524 & 0.523 & 0.523 & 0.493 & 0.476 \\
\hline
\end{tabular}

* A standard amount of NANA, $10 \mu \mathrm{g}$ in $0.5-\mathrm{ml}$ final volume, was tested.

$\uparrow$ Spectrophotometric reading $\left(E_{549}\right)$ of single-tube assays corrected by subtraction of the value for the corresponding time-zero enzyme control.

$\ldots=$ Not done. 
five serial cultures and concentration of a sample of the fifth culture supernate produced a proportional increase in activity. The amount of neuraminidase in the successive washings fell rapidly to trace amounts, but there was release of a significant amount of neuraminidase after ultrasonic treatment of the suspension of $\mathrm{L} 2 \mathrm{Ab}$ cells. By contrast, neuraminidase activity was not detected in any of the equivalent samples from the cultures of strain Hobbs' 2, although the tests were incubated for $24 \mathrm{~h}$.

Table V shows the amount of NANA that was destroyed during incubation with samples of the fifth culture supernates for periods up to $24 \mathrm{~h}$ under conditions equivalent to those of the neuraminidase assay. The supernate of the fifth culture of strain L2Ab produced slight destruction of NANA after incubation for $24 \mathrm{~h}$; this suggests that there is slight NAN-aldolase activity in the culture supernate (although too little to interfere significantly with the 15-min. neuraminidase assay). There was, however, no destruction of NANA by the supernate of the fifth culture of the strain of Hobbs' type 2 and even with this product concentrated five-fold there was only a very slight reduction in the assay value for NANA after incubation for $24 \mathrm{~h}$. This confirms that the results of neuraminidase assays on culture supernates of the strain of Hobbs' type 2 are valid, i.e. that this strain produced no demonstrable extracellular neuraminidase.

Disruption of the washed cells of strain L2Ab and the strain of Hobbs' type 2 liberated NAN-aldolase into the supernate. The results presented in table VI show that in each case the supernate from the third washing of the cells in saline produced no destruction of NANA but that the supernate after disruption of the cells was able to destroy the test dose of NANA during incubation for $24 \mathrm{~h}$. The amount of NAN-aldolase activity in the cell extracts of the two strains appears to be comparable, as judged by the similar rate of NANA destruction during the first $3 \mathrm{~h}$ of the test.

\section{TABLE VI}

Effect of incubating NANA with cell extracts of strain $L 2 A b$ and the Hobbs' type-2 strain for up to $24 \mathrm{~h}$

\begin{tabular}{l|ccccccc}
\hline \multicolumn{1}{c}{ Reaction mixture* } & \multicolumn{5}{c}{$\begin{array}{c}\text { Result of assay for NANA }\left(E_{549}\right) \dagger \text { after incubation of } \\
\text { mixture for stated time (h) }\end{array}$} \\
\cline { 2 - 7 } & 0 & $\frac{1}{2}$ & 1 & 2 & 3 & 24 \\
\hline $\begin{array}{l}\text { NANA+3rd washing of strain L2Ab } \\
\text { NANA+ cell extract of strain L2Ab }\end{array}$ & 0.477 & 0.467 & 0.481 & 0.474 & 0.470 & 0.461 \\
$\begin{array}{l}\text { NANA+3rd washing of Hobbs' } \\
\text { type-2 strain }\end{array}$ & 0.460 & 0.334 & 0.250 & 0.125 & 0.086 & 0.020 \\
$\begin{array}{l}\text { NANA+ cell extract of Hobbs' type-2 } \\
\text { strain }\end{array}$ & 0.485 & 0.502 & 0.494 & 0.487 & 0.489 & 0.492 \\
\hline
\end{tabular}

* A standard amount of NANA, $10 \mu \mathrm{g}$ in $0.5-\mathrm{ml}$ final volume, was tested.

$\uparrow$ Spectrophotometric reading $\left(E_{549}\right)$ of single-tube assays corrected by subtraction of the value for the corresponding time-zero enzyme control. 


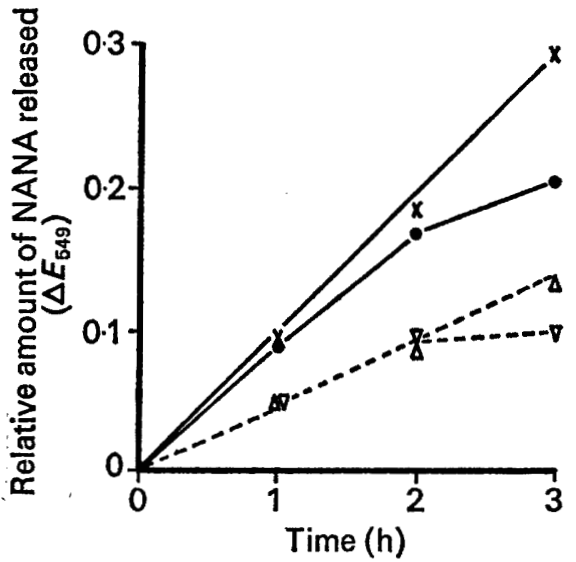

FIG. 3.-Results of neuraminidase assays incubated for periods up to $3 \mathrm{~h}$ in the presence of cell extract of the Hobbs' type-2 strain. The test mixtures (final volume $0.6 \mathrm{ml}$ ) contained: $0.25 \mathrm{ml}$ FVII substrate; $0.15 \mathrm{ml}$ sodium-acetate buffer, $p \mathrm{H} 5.1 ; 0.1 \mathrm{ml} \mathrm{L2Ab}$ cell extract diluted in the acetate buffer; and either $0.1 \mathrm{ml}$ acetate buffer or $0.1 \mathrm{ml}$ undiluted cell extract from the Hobbs' type-2 strain.

$2 \%(v / v) \mathrm{L} 2 \mathrm{Ab}$ cell extract + buffer, $\times-\ldots ; 2 \% \mathrm{~L} 2 \mathrm{Ab}$ cell extract + cell extract from the Hobbs' type-2 strain, $-; 1 \%$ L2Ab cell extract + buffer, $\triangle-\triangle ; 1 \%$ L $2 A$ b cell extract + cell extract from the Hobbs' type- 2 strain, $\nabla-\nabla$. Results corrected by subtraction of the value for the corresponding time-zero test.

Fig. 2 shows the effect of the NAN-aldolase in the L2Ab cell extract when the neuraminidase assay is done at intervals up to $8 \mathrm{~h}$. The amount of NANA released increases rapidly to reach a peak at $1 \mathrm{~h}$ and thereafter there is a progressive fall in assay value; thus the result of the 15 -min. neuraminidase assay on the L2Ab cell extract given in table IV is liable to be an underestimate. Because the cell extract prepared from the Hobbs' type-2 strain contains a similar amount of NAN-aldolase activity, the negative result in the 24-h neuraminidase assay on this sample might have been due to subsequent destruction of the NANA released; however, further studies showed no detectable release of NANA even during the first $3 \mathrm{~h}$ of incubation of assay mixtures containing cell extract of this strain.

To give an indication of the amount of neuraminidase that we could expect to detect in the Hobbs' type-2 cell extract despite its NANA-destroying activity, dilutions of $\mathrm{L} 2 \mathrm{Ab}$ cell extract were assayed in the presence and absence of undiluted cell extract. The results are presented in fig. 3 . The assay values for neuraminidase were reduced by the Hobbs'-2 cell extract in tests incubated for $2-3 \mathrm{~h}$, but even $1 \%$ of the amount of neuraminidase released by ultrasonic treatment of strain-L2Ab cells could clearly be detected in the presence of the cell extract prepared from the Hobbs' type-2 strain.

\section{Discussion}

Neuraminidase-positive strains of $C$. welchii type A produce small amounts of neuraminidase when grown in nutrient broth but large amounts, and 
sometimes very large amounts, in the PPW5 broth that we chose for these studies. We found considerable variation in the amount of neuraminidase produced by strain $\mathrm{L} 2 \mathrm{Ab}$ in serial cultures incubated under apparently identical conditions, even when the PPW5 broth was prepared in a single batch and when we assayed the supernates of the serial cultures in a single experiment.

Collee (1965b) found that four non-haemolytic, heat-resistant food-poisoning strains were neuraminidase negative and Moss et al. (1967) confirmed that 12 reference British food-poisoning strains (Hobbs' types 1-3 and 5-13) were neuraminidase negative. It seemed that it might be generally true that nonhaemolytic, heat-resistant food-poisoning strains did not produce neuraminidase, but Moss et al. (1967) went on to demonstrate an exception with one American isolate that was otherwise indistinguishable from the Hobbs' reference strains. Most of the American food-poisoning isolates that these workers examined differed in one or more characters from the non-haemolytic, heat-resistant Hobbs' strains, and the majority of these American strains did produce neuraminidase. We have now studied 41 of the current British reference food-poisoning strains and found that, whereas 12 of 17 so-called heat-sensitive strains were neuraminidase positive, 20 of 24 heat-resistant strains were neuraminidase negative. Our findings show that, in British as in American food-poisoning strains, the ability to cause food-poisoning is not correlated with lack of neuraminidase production, although the majority of non-haemolytic heat-resistant isolates are neuraminidase negative.

The four heat-resistant strains that we found to be clearly neuraminidase positive include the reference strain of Hobbs' type 13, which was found to be neuraminidase negative by Moss et al. (1967). We found that three other type-13 strains produced neuraminidase, including strains 029 and 153 , which were amongst the strains reported as neuraminidase negative by Collee (1965b). It is possible that our strains might have altered as a result of prolonged storage and subculture, although their characteristics were carefully re-checked to confirm that they were still non-haemolytic and produced heat-resistant spores. PPW5 medium is generally much better for the production of neuraminidase than the media used by Collee in 1965 and it is unlikely that the less sensitive assay procedure then in use, with egg-white as substrate, would have detected the small amounts of neuraminidase produced in some cultures of these strains even in PPW5 broth-for example, in the experiment illustrated in fig. 1. Although the data from this experiment suggest that sequential subculture in PPW5 broth might result in a gradually increased yield of the enzyme, this pattern was not found in subsequent experiments. We have found considerable variation in the amount of neuraminidase produced by strains 029 and 153 in PPW5 broth, but all cultures that we have examined contain neuraminidase activity that is clearly demonstrable by our present methods. We think that our ability to show neuraminidase production by strains 029 and 153 is now probably attributable to developments in our culture and assay procedures; however, even after incubation of tests for $24 \mathrm{~h}$, we found no evidence of neuraminidase production by one other type-13 strain. It thus appears that there is true variation in the ability to produce neuraminidase among strains of a single Hobbs' serotype of $C$. welchii.

Our finding that any peuraminidase-positive strain may vary considerably in its production of the enzyme despite apparently identical conditions of culture led us to assay the supernates of five sequential cultures in tests of an apparently neuraminidase-negative Hobbs' type-2 strain. When strain L2Ab was grown in PPW5 broth at the optimum temperature for neuraminidase production it produced very high yields of the enzyme, which was essentially extracellular; some further neuraminidase could be released by ultrasonic disintegration of the washed cells. When the Hobbs' type-2 strair was grown in parallel under identical conditions, 
no activity was demonstrable in culture supernates even after five-fold concentration, and no neuraminidase was released by ultrasonic disintegration of the cells.

As our assay depends upon the detection of NANA liberated by the neuraminidase, the presence of NAN-aldolase might produce a false negative result. However, there was insignificant NAN-aldolase activity in the culture supernate of the Hobbs' type-2 strain; this confirms the validity of our 24-h neuraminidase assay as a sensitive test for neuraminidase activity and demonstrates that the Hobbs' type-2 strain produces no extracellular neuraminidase (i.e. less than $0.01 \%$ of the neuraminidase produced by strain L2Ab). When the neuraminidase-positive $\mathrm{L} 2 \mathrm{Ab}$ cells were disrupted, the NAN-aldolase released produced some interference with the neuraminidase assay. A similar amount of NAN-aldolase was released from the neuraminidase-negative Hobbs' type-2 strain, but our further experiments showed that this would not prevent the demonstration of quite small amounts of neuraminidase-as little as $1 \%$ of that associated with L2Ab cells. Thus we now have clear evidence that British food-poisoning strains of $C$. welchii include some that are neuraminidase positive and some that still cannot be shown to produce neuraminidase despite considerable advances in our ability to detect the enzyme.

Whilst it is unlikely that neuraminidase is concerned in the mechanism of pathogenicity of $C$. welchii in the gut, it is possible that the enzyme plays a part in gas gangrene. Hauschild and Thatcher (1968) found that whereas non-haemolytic, heat-resistant food-poisoning strains did not produce experimental gas gangrene in animals, and that this was correlated with production of very low amounts of the lethal $\alpha$-toxin, some non-haemolytic but heatsensitive food-poisoning strains did produce gas gangrene if injected in large numbers. There was a clear but imperfect correlation between virulence and in-vitro production of $\alpha$-toxin. Although the mechanism of pathogenicity of $C$. welchii in wound infection has long been associated with the organism's ability to produce $\alpha$-toxin (Evans, 1945; MacLennan, 1962), Bullen (1970) has developed an interesting argument to suggest that other factors may be more important. It might be argued that the neuraminidase, which is produced in close association with the $\alpha$-toxin by many strains, plays a hitherto undetected role as an aggressin (Collee, 1965b) and that anti-neuraminidase in C. welchii antitoxin (see Warren and Spearing, 1963) may contribute to its protective effect. Under these circumstances, the organism's infectivity and virulence might depend upon its early production of neuraminidase in vivo. Our ability to define neuraminidase-negative strains might now be exploited to test this suggestion.

\section{SUMMARY}

The production of neuraminidase by a classical strain of Clostridium welchii (C. perfringens) type A was studied. Good yields were produced in $5 \%$ Proteose Peptone-water medium (PPW5); the enzyme was essentially extracellular but some further neuraminidase could be released by ultrasonic disintegration of the cells. This also released $\mathrm{N}$-acyl neuraminic acid-aldolase (NAN-aldolase) and the degree to which this interferes with the assay for neuraminidase was evaluated.

Forty-one British reference food-poisoning strains of $C$. welchii type A were examined for extracellular neuraminidase production in PPW5. Twelve 
of 17 strains that produce so-called heat-sensitive spores were neuraminidase positive whereas 20 of 24 strains that are non-haemolytic and produce very heat-resistant spores were neuraminidase negative. Variation was found in the ability to produce neuraminidase among strains of a single Hobbs' serotype; four Hobbs' type-13 strains produced neuraminidase but a fifth did not. Disruption of the cells of a Hobbs' type-2 strain that did not produce any extracellular neuraminidase released NAN-aldolase but there was no evidence of cell-associated neuraminidase. British food-poisoning strains of $C$. welchii type $A$ thus include some that are clearly neuraminidase positive and some that still cannot be shown to produce neuraminidase. There is no correlation between lack of neuraminidase production and the ability to cause food poisoning, although the majority of non-haemolytic heat-resistant strains do not produce neuraminidase. It remains possible that neuraminidase may play a part in $C$. welchii gas gangrene; it is suggested that the ability to define neuraminidase-negative strains may now be of value in investigating this possibility.

We thank Mr Robert Brown and his colleagues for skilled technical assistance, and Dr Betty Hobbs and her colleagues at the Central Public Health Laboratory, Colindale, for their generous help in providing strains. We gratefully acknowledge the valuable work of Dr Yvonne Jardine and Dr Richard Cowie, who were financially supported by the Agricultural Research Council (Grant AG 15/57) to undertake preliminary studies on the Edinburgh food-poisoning strains.

\section{REFERENCES}

BULLEN, J. J. 1970. Role of toxins in host-parasite relationships. In Microbial toxins, vol. 1, edited by S. J. Ajl, S. Kadis and T. C. Montie, New York and London, p. 233.

ColleE, J. G. 1965a. A myxovirus receptor-inactivating agent occurring in cultures of Clostridium welchii. J. Path. Bact., 90, 1.

COLleE, J. G. 1965b. The relationship of the haemagglutinin of Clostridium welchii to the neuraminidase and other soluble products of the organism. J. Path. Bact., 90, 13.

Evans, D. G. 1945. The in-vitro production of $\alpha$-toxin, $\theta$-haemolysin and hyaluronidase by strains of Clostridium welchii type A, and the relationship of in-vitro properties to virulence for guinea-pigs. J. Path. Bact., 57, 75.

Fraser, A. G. AND Smith, J. K. 1975. Preparation of a glycoprotein fraction from pooled human plasma and its evaluation as a substrate for the assay of Clostridium welchii (C. perfringens) neuraminidase. J. med. Microbiol., 8, 235.

Hauschild, A. H. W. and Thatcher, F. S. 1967. Experimental food poisoning with heatsusceptible Clostridium perfringens type A. J. Fd Sci., 32, 467.

Hauschild, A. H. W. AND Thatcher, F. S. 1968. Experimental gas gangrene with foodpoisoning Clostridium perfringens type A. Can. J. Microbiol., 14, 705.

Hоввs, B. C. 1969. Clostridium perfringens and Bacillus cereus infections. In Food-borne infections and intoxications, edited by H. Riemann, New York and London, p. 131.

Hobrs, B. C., Clifford, W., Ghosh, A. C., Gilbert, R. J., Kendall, M., Roberts, D. and WIENEKE, A. A. 1973. Sampling of food and other material for bacteriological and ecological studies. In Sampling-microbiological monitoring of environments, Society for Applied Bacteriology Technical Series, no. 7, edited by R. G. Board and D. W. Lovelock, London and New York, p. 233.

Hobrs, B. C., Smtth, M. E., Oakley, C. L., Warrack, G. H. and Cruickshank, J. C. 1953. Clostridium welchii food poisoning. J. Hyg., Camb., 51, 75. 
Maclennan, J. D. 1962. The histotoxic clostridial infections of man. Bact. Rev., 26, 177. Moss, C. W., Schekter, M. A. AND CherRy, W. B. 1967. Distribution of neuraminidase among food-poisoning strains of Clostridium perfringens. Appl. Microbiol., 15, 718. Sutton, R. G. A. AND Hobrs, B. C. 1968 . Food poisoning caused by heat-sensitive Clostridium welchii. A report of five recent outbreaks. J. Hyg., Camb., 66, 135.

WARREN, L. AND SPEARING, C. W. 1963. Sialidase (neuraminidase) of Corynebacterium diphtheriae. J. Bact., 86, 950. 